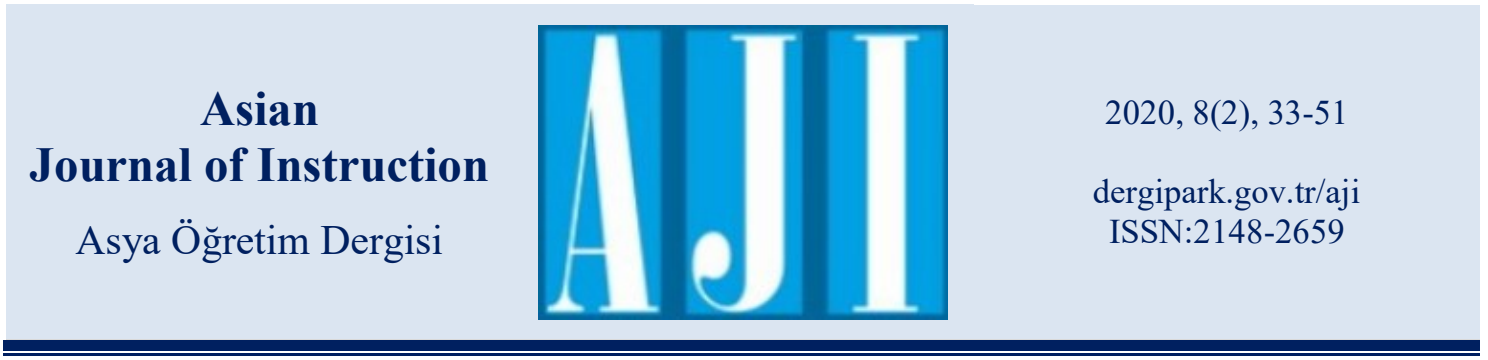

Kabul Tarihi: 04/12/2020

Yayınlanma Tarihi: 26/12/2020

\title{
Sekizinci Sınıf Öğrencilerinin Atatürk İlkelerine Yönelik Bilişsel Yapılarının Kelime İlişkilendirme Testiyle İncelenmesi
}

\author{
Sezgin Elbay ${ }^{1}$
}

Elbay, S. (2020). Sekizinci sınıf öğrencilerinin Atatürk ilkelerine yönelik bilişsel yapılarının kelime ilişkilendirme testiyle incelenmesi. Asya Öğretim Dergisi, 8(2), 33-51. https://doi.org/10.47215/aji.806097.

\section{$\ddot{\mathbf{O} z}$}

Ortaokul T.C. İnkılap Tarihi ve Atatürkçülük Dersi Öğretim Programı’nda (2018) yer alan Atatürk ilkelerinin kavramlara dayalı olarak inşa edildiği belirlenmiştir. Dolayısıyla 8. sınıf öğrencilerinin Atatürk ilkelerine ilişkin bilişsel yapılarında ne gibi çağrışım ve anlam ağları olduğunu ortaya koymak öğretim programının uygulamadaki durumunu betimlemek için gerekebilir. Bu bağlamda araştırmanın amacı, Ortaokul T.C. İnkılap Tarihi ve Atatürkçülük dersinde öğrencilerin Atatürk ilkelerine yönelik bilişsel yapılarını kelime ilişkilendirme testi aracılığıyla incelemektir. Bunun için tarama modeline uygun olarak bir araştırma desenlenmiştir. Araştırmanın çalışma grubunu, 2019 yılında, Sakarya kentinin bir ilçesinde bulunan üç devlet ortaokulunun 8. sinıfında öğrenim gören 100 öğrenci oluşturmuştur. Araştırmanın verileri, kelime ilişkilendirme testi aracıllğıyla toplanmıştır. Toplanan veriler üzerinde betimsel analiz yapılmıştır. Analizler sonucunda öğrencilerin bilişsel yapısında Cumhuriyetçilik, Halkçılık, Milliyetçilik ve Laiklik ilkelerinin birbiriyle ilişkili olduğu ve bütüncül bir ağ oluşturacak şekilde bir arada bulunduğu sonucuna ulaşılmıştır. Ayrıca ilkelere verilen yanıt kelimeler incelendiğinde, öğrencilerin Atatürk'ten bağımsız ve kopuk bir şekilde Atatürk ilkelerini algılamaya çalıştıkları ve Laiklik ilkesiyle ilgili kavram yanılgılarının temelinde dinsel devlet algısının olduğu söylenebilir.

Anahtar Kelimeler: Ortaokul T.C. İnkılap Tarihi ve Atatürkçülük dersi, kelime ilişkilendirme testi, öğrencilerin bilişsel yapıları

\section{Examination of $8^{\text {th }}$ Students' Cognitive Structures Towards Atatürk's Principles Using Word Association Test}

\begin{abstract}
It has been determined that Atatürk's principles were built based on concepts in middle school T.R. History of Revolution and Kemalism Course Curriculum (2018). Therefore, it may be necessary to reveal what kind of connotation and meaning networks there are in the cognitive structures of $8^{\text {th }}$ grade students regarding Atatürk's principles to describe the situation of the curriculum in practice. In this context, the aim of the study is to examine and determine students' cognitive structures towards Atatürk's principles through the word association test in the T.R. History of Revolution and Kemalism course in middle school level. Screening model was used for this. The study group of the research consisted of 100 students studying in the $8^{\text {th }}$ grade of three public middle schools in a district of Sakarya in the 2019 year. The research data were collected through the word association test. Descriptive analysis was made on the collected data. As a result of the analysis, it was concluded that the principles of Republicanism, Populism, Nationalism and Secularism were interrelated in the cognitive structure of the students and were found together to form a holistic network. In addition, when the words given to the principles are examined, it can be said
\end{abstract}

${ }^{1}$ Dr., Milli Eğitim Bakanlığı, Sakarya, ORCID: 0000-0002-0601-8063, sezgin_elbay@hotmail.com 
Sekizinci Sınıf Öğrencilerinin Atatürk İlkelerine Yönelik Bilişsel Yapılarının Kelime İlişkilendirme Testiyle İncelenmesi

that the students try to perceive Atatürk's principles independently and disconnected from Atatürk and that the religious state perception is the basis of the misconceptions about the principle of secularism.

Keywords: Middle School T.R. History of Revolution and Kemalism course, word association test, students' cognitive structures

\section{Giriş}

Tarih, geçmişte meydana gelen olayları yer, zaman ve kişi unsurlarına uygun olarak ele almayı gerektirmektedir. Bu kapsamda tarihi araştırma yapan kişiler bu incelemeleri yaparken, hem kendi hayatlarını hem de milletinin yaşadıklarını göz önünde bulundurarak geçmişteki olayları anlamaya çalışabilir. Böylece geçmişte meydana gelen olayları tarihsel kişiliklerin (tarihte önemli işler yapan kişiler) yaptıklarıyla birlikte analiz edebilir. Başka bir anlatımla birey, geçmiş dönemde meydana gelen olayları analiz ederek, tarihsel kişilikleri ve onların yaptıklarını belli perspektifler açısından irdeleyebilir. $\mathrm{Bu}$ irdelemenin olması amacıyla öğretim programlarına tarihsel olayları kapsayan çeşitli dersler konulmuştur. Bu derslerden biri, ortaokul düzeyinde okutulan T.C. İnkılap Tarihi ve Atatürkçülük dersidir.

Ortaokullarda T.C. İnkılap Tarihi ve Atatürkçülük dersi birden çok hedefi gerçekleştirmek için okutulmaktadır. Öncelikle bu ders aracılığıyla, Türkiye Cumhuriyeti Devleti’nin kültürel özellik ile değerlerinin, genç nesiller tarafindan içselleştirilmesini sağlamak ve genç nesilleri ulusal amaçlar doğrultusunda yetiştirmek (Öztaş \& Kıliç, 2017), ikinci olarak Atatürk ilke ile inkılaplarının toplumsal, siyasal ve ekonomik kalkınmadaki yerini anlamak ve genç nesillerin bu kavramları yaşamları boyunca içselleştirmelerini sağlamak (Ezer, Ulukaya \& Kaçar, 2016) hedeflenmektedir. $\mathrm{Bu}$ hedefleri gerçekleştirmek için de Ortaokul T.C. İnkılap Tarihi ve Atatürkçülük Dersi Öğretim Programları geliştirilmiş veya güncellenmiştir.

Ortaokul T.C. İnkılap Tarihi ve Atatürkçülük Dersi Öğretim Programı'nda (2018) yedi ünitenin bulunduğu görülmektedir. Bunlardan dördüncü ünitenin ağırlıklı olarak Atatürk ilkelerine ayrıldığ 1 söylenebilir. Atatürk ilkeleri incelendiğinde ise Atatürk ilkelerinin kavramlara dayalı olarak inşa edildiği belirlenmiştir. Kavram, bir düşünce ya da onun özelliklerini sinıflandırmak amacıyla işe koşulan etiket olarak tanımlanabilir (Jadallah, 2000). Dolayısıyla kavramlar, somut veya soyut özelliklere sahip olabilir (Ülgen, 2004). Bu bağlamda Atatürk ilkelerini oluşturan kavramların soyut bir yapıya sahip olduğu söylenebilir. Bundan dolayı öğrencilerin bu tür kavramları anlaması ve anlamlandırması zor olabilir. Oysaki kavramlar anlaşılmadığında yanlış veya eksik öğrenmelere neden olabilmektedir (Sabanc1, 2008). Yanlış veya eksik öğrenmelerin olmaması için bilişsel yapıda kavramların yapılandırılarak depolanması gerekebilir.

Öğrencilerin belli konularla ilgili bilişsel yapısında ne kadar çok yapılandırılmış kavram varsa, konunun anlaşılması ve olaylar arasında ilişkilerin kurulması daha kolay olabilir (Er Tuna, 2018). Bu bağlamda kavramlar, uzun süreli bellekte ana bilişsel yapıların oluşması ve yeni gelen bilgilerin anlamlı bir biçimde depolanmasına katkı sağlayabilir (Candan, 2009). Böylece soyut kavramlar, anlam ağı biçiminde örgütlenebilir ve kavramlar arasında ilişki kurulabilir. Bu durum da bilişsel yapıları geliştirebilir.

Bilişsel yapılar, kavramların bağlantı kurucu ağlarda tasarımlanması sonucunda ortaya çıkan harita benzeri yapılar olarak tanımlanmaktadır (McClelland \& Rogers, 2003). Bu kapsamda farklı kavramlar ve onların özellikleri bir bağlantı ağında temsil edilebilmektedir. Dolayısıyla bağlantı ağındaki kavramlar, ilişkisel bir şekilde bir araya gelerek kavramın, bilişsel yapıdaki bir görselini sunabilmektedir (Goldstein, 2013). Bu amaçla Rogers ve McClelland (2004) tarafından yapılan çalışmada, bilişsel yapıda temsil edilen bir kavramın çeşitli şekillerde 
etkinleştirilmesi sonucunda, o kavramın bağlantı ağındaki birimlerine doğru etkinin yayıldığı saptanmıştır. Bağlantı ağını öğrenme süreci ise ilişkisel ve bilimsel olarak doğru tanımlanan kavramları içerecek bir şekilde olmaktadır. Aksi takdirde kavram yanılgıları olabilir. Bunların düzeltilmesi de, yeni bir kavramı öğrenmekten daha zor olmaktadır (Ülgen, 2004).

Kavram yanılgıları, bireylerin herhangi bir olay, olgu veya konu hakkında sahip oldukları bilimsel olarak tamamen doğru olmayan düşünce ve anlayışları olarak tanımlanabilir (Güneş, 2006). Bu kapsamda kavram yanılgılarının, bilimsel olarak kabul edilen ifadelerden farklı anlam içeriklerine sahip bilişsel modeller olduğu söylenebilir (Yakışan vd., 2007). Başka bir anlatımla kavram yanılgıları, bilgi eksikliğinden dolayı kavramları yanlış bir şekilde tanımlamak değil, yanlış öğrenmeler sonucunda oluşan değişime dirençli anlam yapılarıdır. Bu yanılgıların olmaması için kavramların bilimsel tanımına uygun olarak öğrenilmesi gerekebilir. Böylece kavramlar, doğru bir şekilde uzun süreli belleğe aktarılarak yeni üretilecek bilgiye temel oluşturulabilir. Bunun sonucunda kavramlar arasında etkileşimle birlikte anlamlı ve tutarlı öğrenmeler olabilir. Özetle herhangi bir kavramla ilgili bilişsel yapıların bilinmesi, kavramlar arasındaki ilişkilerin anlaşılması ve kavram yanılgılarının ortaya çıkarılmasını sağlayabilir.

Bilişsel yapıların ortaya çıkarılması için birçok tekniğin işe koşulduğu görülmektedir. $\mathrm{Bu}$ tekniklerden biri de kelime ilişkilendirme testi (KİT)'dir. KİT, öğrencilerin belirli bir konu ile ilgili olarak bilişsel yapı ve kavram ağlarını anlamayı sağlayan, uzun süreli bellekteki kavram ve bilgiler arasındaki ilişkilerin yeterliğini belirlemeye yardımcı olan bir teknik (Bahar \& Özatlı, 2003) olarak tanımlanabilir. Başka bir anlatımla KİT, öğrencilerin bilişsel yapılarını ve bu yapılardaki kavramlar arasındaki bağları; yani anlam ağını ortaya çıkarmayı sağlayan, uzun süreli bellekteki kavramlar arasındaki ilişkilerin yeterlik derecesini ya da anlamlı olup olmadığını saptamaya yarayan tekniklerden biridir (Bahar, Johnstone \& Sutcliffe, 1999). Böylelikle kavramların öğrencilerde oluşturduğu çağrışımlar ile öğrencilerin, bir konuyla ilgili bilişsel yapılarındaki anahtar kavramlar ve hâlihazırdaki kavram yanılgıları saptanabilir (Er Tuna, 2018). Bu bağlamda KİT'ler ile ilgili birçok çalışmanın yapıldığı görülmektedir.

KİT'ler ile ilgili Atatürk ilkeleri ve öğrencilerin farklı alanlardaki bilişsel yapılarına ilişkin çeşitli çalışmaların yapıldığı görülmektedir. Bu bağlamda Akman ve Koçoğlu (2016) tarafından yapılan çalışmada, 8. sınıf öğrencilerinin Atatürk ilkelerini hangi kavramlarla ilişkilendirdikleri ortaya çıkarılmaya çalışılmıştır. Bazı araştırmalarda ise öğretmen adaylarının, Atatürk ilkelerine ilişskin bilişsel yapıları incelenmiştir (Er Tuna, 2018; Işıklı, Taşdere, Göz, 2011). İnel, Akar ve Üztemur (2016) tarafindan yapılan çalışmada ise 8. sınıf öğrencilerinin, yönetim şekillerine ilişkin bilişsel yapıları tespit edilmeye çalışılmıştır. Bunların yanı sıra 5. sınıf öğrencilerinin, Türkiye' deki bölgelere ilişkin kavram yanılgıları incelenmiştir (Öztürk \& Yılmaz Özcan, 2017). Öte yandan ortaokul öğrencilerinin demokratik değerlere (adalet, özgürlük, eşitlik, sorumluluk, duyarlık, hoşgörü, çoğulculuk, insan haklarına saygı, eleştirel düşünme, uzlaşma) ilişkin bilişsel yapılarının belirlenmeye çalışıldığı da görülmüştür (Dinç, Sezer, Üztemur \& İnel, 2018). Bunlara ilaveten öğretmen adaylarının, sosyal bilgiler ile sosyal bilimler kavramlarına ilişkin bilişsel yapıları incelenmiştir (Deveci, Çengelci Köse \& Gürdoğan Bayır, 2014). Karakuş (2019) tarafından yapılan çalışmada ise öğretmen adaylarının, doğal afetlere ilişkin bilişsel yapıları belirlenmeye çalışılmıştır. Özetle, bilişsel yapıların KİT aracılığıyla saptanmasına ilişkin birçok çalışma yapılmasına rağmen, araştırmalarla 8. sınıf öğrencilerinin Atatürk ilkelerine ilişkin bilişsel yapı ve bununla bağlantılı olarak ilkelerle ilgili kavram yanılgılarının ortaya çıkarılamadığı söylenebilir.

Atatürkçü düşünce sisteminin temelinde Atatürk ilkeleri bulunmaktadır (Er Tuna, 2018). Bunun için 8. sınıf öğrencilerinin Atatürk ilkelerine ilişkin bilişsel yapılarında ne gibi çağrışım ve anlam ağları olduğunu ortaya koymak gerekmektedir. Böylece Atatürk ilkeleri kapsamında, öğretimsel bir müdahale yapmak ve öğrencilerin kavrama ile kavram yanılgılarını saptamak 
olanaklı olabilir. Bu bağlamda araştırmanın amacı, 8. sınıf öğrencilerinin Atatürk ilkelerine ilişkin bilişsel yapılarını KİT aracılığıyla incelemektir. Araştırmanın alt soruları ise şu şekildedir: 8. sınıf öğrencilerinin Atatürk ilkelerine ilişkin;

a) Bilişsel yapıları nasıldır?

b) Kavram yanılgiları nelerdir?

\section{Yöntem}

\subsection{Araştırma Modeli}

Araştırma, tarama modelinden yararlanılarak yapılmıştır. Tarama modeli, geniş bir kitlenin herhangi bir konuyla ilgili görüş ya da özelliklerinin betimlenmesi amacıyla işe koşulmaktadır (Fraenkel \& Wallen, 2006). Böylece geçmişte veya halen etkisini sürdüren bir durum olduğu gibi ortaya koyulmaya çalışılmaktadır (Karasar, 2017). Bu araştırmada, 8. sınıf öğrencilerinin Atatürk ilkelerine ilişkin bilişsel yapıları olduğu gibi betimlenmeye çalışıldığı için tarama modeli işe koşulmuştur.

\section{2. Çalışma Grubu}

Araştırmanın çalışma grubunu, 2019-2020 yılında, Sakarya kentinin bir ilçesinde bulunan üç ortaokulun 8. sınıfina devam eden 100 öğrenci oluşturmuştur. Araştırmanın amacında ifade edilen Atatürk ilkeleri, Ortaokul T.C. İnkılap Tarihi ve Atatürkçülük dersinde işlendiği ve Ortaokul T.C. İnkılap Tarihi ve Atatürkçülük dersi 8. sinıfta okutulan bir ders olduğu için çalışma grubu olarak 8. sınıf öğrencileri araştırmaya dâhil edilmiştir. Okulların seçiminde ise, basit seçkisiz örnekleme yöntemi kullanılmıştır. Bu bağlamda Sakarya kentinin bir ilçesinde yer alan üç ortaokul, şans yoluyla belirlenmiş ve üç ortaokulda araştırma yapılmıştır.

Araştırmaya katılan 100 gönüllü öğrenciden 12'si, veri toplama aracı olan KİT'i amacı dışında kullandığı için (çizme ve tahrif etme) araştırmadan çıkarılmış, 88 öğrenciden toplanan veriler çözümlenmiştir. Araştırmaya dâhil edilen bu öğrencilerin 55'i kız, 33’ü erkektir.

\subsection{Veri Toplama Araçları}

Araştırmada, veri toplama aracı olarak, 8. sınıf öğrencilerinin Atatürk ilkelerine yönelik bilişsel yapılarını ortaya çıkarmak için KİT işe koşulmuştur. KİT, bilişsel yapıların ortaya çıkarılmasında yaygın olarak işe koşulan tekniklerden biridir (Bahar \& Özatl1, 2003). KİT ile öğrencilerden, herhangi bir konuda, verilen anahtar kavramların kendilerinde çağrıştırdığ kavramları yazmaları istenmektedir (Deveci vd., 2014). KİT'in hazırlanması için konuyla ilgili 5 veya 10 tane anahtar kavram belirlenmektedir. Bu kavramlar, sayfa içinde alt alta gelecek şekilde 10-15 kere yazılmaktadır. Birinci sayfada uygulama yönergesine, 2. sayfada ise bunun bir örneğine yer verilmektedir. Öğrencilerden anahtar kavramın çağrıştırdığı sözcükleri 30 saniye içinde yazmaları istenmektedir. Bu aşamada seçilen anahtar kavramların birbirini izleyen sayfalarda görülemeyecek şekilde organize edilmesi gerekmektedir. Çünkü bu, zincirleme yanıt vermeyi ve kavram yazma riskini önlemeyi sağlayabilir. Ayrıca öğrenci, sözcüğ̈ her yazdığında anahtar kavrama bakmazsa, anahtar kavram yerine yanıt olarak yazdığı kavramın aklına getirdiği sözcükleri yazabilir. Bu durum da KITT'in temel amaçlarını gerçekleştirmeye zarar verebilir (Karakuş, 2019). Son olarak öğrenciler, tüm anahtar kavramları yanıtladıktan sonra, KİT'ler toplanmakta ve değerlendirilmeye alınmaktadır (Işıklı vd., 2011). KİT'e verilen yanıtlar, uzun süreli bellekten geri getirilen kavramların, aralarındaki ilişkinin anlamlı olup 
olmadığını belirlemeye yaramaktadır (Bahar vd., 1999). Yani KİT aracılı̆̆ıyla kavramlar arasında kurulan ilişki ve bağları açığa çıkarmak mümkün olmaktadır (Atasoy, 2004).

$\mathrm{Bu}$ araştırmada kavram olarak Atatürk ilkeleri seçilmiş; buna yönelik olarak KİT oluşturulmuștur. KIT'i olușturmak için Atatürk ilkeleri (Cumhuriyetçilik, Milliyetçilik, Laiklik, Halkçılık, Devletçilik ve İnkılapçılık) anahtar kavramlar olarak belirlenmiştir. KìT, iki bölüm halinde düzenlenmiştir. Birinci bölümde 8 . sınıf öğrencilerinin cinsiyet bilgileri, 2. bölümde ise kavramlar bulunmaktadır. Kavramların bulunduğu 2. bölüm aşağıdaki gibi organize edilmiştir:

Laiklik

Laiklik

Laiklik

Laiklik

Laiklik

İlgili Cümle

\subsection{Veri Toplama Süreci}

KİT'te her anahtar kavram bir sayfada yer almıştır. Öğrencilerin zincirleme yanıt verme olasılığını yok etmek için her bir anahtar kavramın alt alta yazılması (Bahar \& Özatlı, 2003) gerekmiştir. Oluşturulan KİT, daha sonra 8. sınıf öğrencilerine dağıtılmış, onlara KİT ve amacıyla ilgili çeşitli bilgiler verilmiştir. Ardından öğrencilere KİT'in yönerge bölümünde bir örnek sunulmuştur. Daha sonra öğrencilere her bir anahtar kavram ile ilgili akıllarına gelenleri yazmaları için 30-45 saniye aralığında süre verilmiştir. Bu süre bittikten sonra diğer anahtar kavrama geçilmiş; böylece her bir anahtar kavram, öğrencilere eşzamanlı olarak uygulanmıştır. Buna ek olarak öğrenciler, anahtar kavramların altında yer alan ilgili cümle bölümünü de doldurmuşlardır. $\mathrm{Bu}$ sayede öğrencilerin, Atatürk ilkeleri (kavramlar) ile ilgili çağrışım yapmaları ve çeşitli ilişkiler kurmaları sağlanmaya çalışılmıştır.

\subsection{Verilerin Analizi}

KİT ile toplanan veriler üzerinde betimsel analiz yapılmıştır. Bu bağlamda Atatürk ilkelerine yanıt olarak verilen sözcükler incelenmiş ve bu sözcüklerin frekansları (tekrarlanma sıklığı) bir tabloda gösterilmiştir. Ardından frekanslar göz önünde bulundurularak öğrencilerin Atatürk ilkelerine ilişkin bilişsel yapıları kesme noktası tekniği (Bahar vd., 1999) ile ortaya çıkarılmaya çalışılmıştır. Bu teknikte KİT’te en sık yanıtlanan sözcügün üç-beş sayı aşağısı kesme noktası olarak kabul edilmektedir. Yanıtlar, yanıt frekansının üzerinde bulunduğu için ilk bölüme yazılmaktadır. Ardından kesme noktası belli aralıklarla aşağı doğru inmektedir (Bahar \& Özatlı, 2003). Kesme noktasında 30-39 aralığında yer alan kavramlar, öğrencilerin bu kavramları 30-39 arasında yanıtladığı anlamına gelmektedir. $\mathrm{Bu}$ araştırmada kesme noktas1 10 ve yukarıs1 alınmış, 10'un aşağısında kalan yanıt sözcükler kavram ağına yazılmamıştır. Belirlenen kesme noktalarına göre kavram ağları hazırlanmıştır.

Kavram ağı öğrencilerin bir konuyla veya kavramla ilgili düşüncelerini yazılı öğretim araçlarındaki kavram ve ilkelerle uyumlu olacak bir şekilde sergilemeye yarayan grafiksel bir araçtır. Ayrıca kavram ağları birbirleriyle ilişkili kavramların farklı kategorilerde temsil edilmesini sağlayan görsel bir haritalama tekniğidir. Bu nedenlerle KİT'ten elde edilen sonuçlar yaygın bir şekilde kavram ağı veya zihin haritası işe koşularak somutlaştırılmaya çalışılmaktadır (Er Tuna, 2018). Araştırmada kavram ağlarında, belirlenen kesme noktalarında yer alan anahtar kavramlara ilişkin belirtilen sözcükler ve bunlar arasındaki ilişkiler gösterilmiştir. Örneğin, kesme noktası 10-19 aralığında ise verilen kavramlara ilişkin belirtilen sözcükler o aralığa yönelik belirlenen renge uygun olarak boyanarak sunulmuştur. KİT'te bulunan ilgili cümleler 
Sekizinci Sınıf Öğrencilerinin Atatürk İlkelerine Yönelik Bilişsel Yapılarının Kelime İlişsilendirme Testiyle İncelenmesi

ise kavrama yönelik bilimsel bilgi içerip içermediği ve kavram yanılgısına sahip olup olmadığ bakımlarından analiz edilmiştir. Analizler sonunda cümleler, kavrama ilişkin bilimsel bilgi ve kavram yanılgısı başlıkları altında sınıflandırılmış ve bunların frekansları hesaplanmıştır. Ardından bunlara iliş̧kin doğrudan alıntılara yer verilmiştir.

\subsection{Geçerlik ve Güvenirlik}

Geçerliği sağlamak için elde edilen veriler, yanıtların boş bırakılma durumu, yanıtların bilimsel bilgi içerip içermediği ve kodlama sürecinin toplanan tüm formlarda aynı olup olmadığına (Cohen ve Manion, 1998) yönelik olarak incelenmiştir. İnceleme sonucunda öğrencilerin verdiği yanıtlar bilimsel bilgi ve kavram yanılgısı başlıkları altında toplanmış ve bunlar bulgular bölümünde sunulmuştur. Güvenirlik için de akran denetimi sağlanarak (Glesne, 2015), araştırma sürecine ilişkin sosyal bilgiler alanında 2 alan uzmanıyla bilgi paylaşımında bulunulmuş ve onların görüş, öneri ile değerlendirmeleri araştırma sürecine yansıtıllmıştır.

\subsection{Etik Kurul İzin}

Yapılan bu araştırmanın verileri 2019 yılında toplandığı için Etik Kurul izni alınmamıştır. Öğrenciler araştırmaya gönüllü olarak katılmışlardır. Çalışma grubundaki öğrencilere kod isim verilerek gizlilik sağlanmıştır.

\section{Bulgular}

Atatürk ilkelerine yönelik üretilen kelimeler ve bunların sıklıkları Tablo 1'de gösterilmiştir:

Tablo 1. Atatürk İlkelerine Yönelik Yazılan Kelimeler ve Kelimelerin Sıklıkları

\begin{tabular}{|c|c|c|c|c|c|c|}
\hline \multirow[t]{2}{*}{ Yanit Kelimeler } & \multicolumn{6}{|c|}{ Anahtar Kavramlar } \\
\hline & 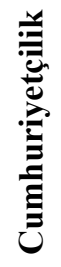 & 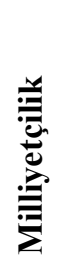 & 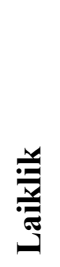 & 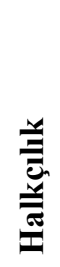 & 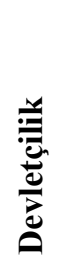 & 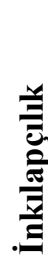 \\
\hline Bağımsızlık & 10 & 22 & & 4 & & 2 \\
\hline Özgürlük & 14 & 6 & 10 & 8 & & 2 \\
\hline Milletvekilleri & 2 & 4 & & & & \\
\hline Oy verme & 28 & & & 8 & & \\
\hline Oy pusulası & 20 & 4 & 2 & 6 & 2 & 2 \\
\hline Seçim & 12 & 2 & & 4 & & \\
\hline Din & & & 41 & & 4 & 2 \\
\hline Namaz & & & 20 & & & \\
\hline Cami & & & 22 & & & \\
\hline Fabrika & & & & & 34 & 14 \\
\hline Market & & & & & 2 & 2 \\
\hline Seçme ve seçilme & 32 & 6 & & 2 & & 2 \\
\hline Kızların eğitim görmesi & 6 & & & 4 & & \\
\hline Yabancı okulların kapatılması & 2 & & & & & \\
\hline Eşitlik & 16 & 8 & 2 & 48 & & 4 \\
\hline Şapka Kanunu & & 4 & 6 & & 2 & 6 \\
\hline Millet & 6 & 28 & & 18 & 2 & 2 \\
\hline Birlik ve beraberlik & 2 & 8 & & 6 & & \\
\hline
\end{tabular}


Sezgin ELBAY

Tablo 1. (devamı)

\begin{tabular}{|c|c|c|c|c|c|c|}
\hline \multirow[t]{2}{*}{ Yanit Kelimeler } & \multicolumn{6}{|c|}{ Anahtar Kavramlar } \\
\hline & & 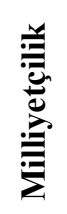 & 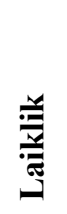 & 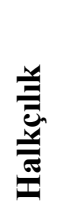 & 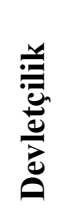 & 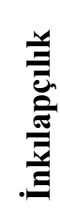 \\
\hline Eğitim & & & 2 & 2 & & \\
\hline İnanç & & & 2 & & & \\
\hline Laiklik & & & & & & 2 \\
\hline Yenilik & & & 10 & 2 & 4 & 48 \\
\hline Milli egemenlik & 6 & 4 & & & & \\
\hline Kadın ve erkek eşitliği & 4 & & & 10 & & \\
\hline Cumhurbaşkanı & 12 & & & & 6 & \\
\hline Ülke & 2 & & & & & \\
\hline İnsanlar & 2 & & 2 & 6 & & \\
\hline Mühür & 6 & & & & & \\
\hline Türk & 2 & 28 & & & & \\
\hline Türkiye & 2 & 4 & & & 2 & \\
\hline Asker & 2 & 4 & & 2 & 2 & \\
\hline Şehit & & 4 & & & & \\
\hline Türk Bayrağı & 10 & 24 & 2 & 4 & 8 & 4 \\
\hline Toplum & & 2 & & 14 & & \\
\hline Şehit anneleri & & 2 & & & & \\
\hline Çocuklar & & 2 & & & & \\
\hline Okul & 2 & 6 & 4 & & 18 & 36 \\
\hline Savaş & & 2 & & & 2 & 4 \\
\hline Sosyal devlet & & & & 4 & & \\
\hline Yardım & & & & 2 & & \\
\hline Yoksullar & & & & 2 & & \\
\hline Engelliler & & & & 2 & & \\
\hline Aile & & & & 2 & & \\
\hline Dinsel Özgürlük & & & 30 & & & \\
\hline Medrese & & & 8 & & 2 & \\
\hline Devlet & 2 & 4 & 8 & 4 & 18 & 4 \\
\hline Ekonomi & & & & & 34 & 10 \\
\hline Araba & & & & & & 2 \\
\hline Kilık kıyafet & & 2 & 4 & & 2 & 8 \\
\hline İthalat & & & & & & 2 \\
\hline Miting & 4 & & & & & \\
\hline Demokrasi & 24 & & & & & \\
\hline Adalet & 8 & & & 18 & 2 & \\
\hline Din ve devlet işlerinin birbirinden ayrılması & & & 12 & & & \\
\hline Sanayi & & & & & 8 & 2 \\
\hline Para & & & & & 10 & \\
\hline Devrim & & & & & & 2 \\
\hline Saç ve sakal & & & & & & 2 \\
\hline Seçmen kâğıd 1 & 8 & & 2 & 2 & 2 & 2 \\
\hline Vatan & & 12 & & 2 & & \\
\hline Akılcılık ve bilimsellik & & & 16 & & 2 & 2 \\
\hline Eğitim birliği & & & 2 & & & \\
\hline Özel sektör & & & & & 12 & 2 \\
\hline
\end{tabular}


Sekizinci Sınıf Öğrencilerinin Atatürk İlkelerine Yönelik Bilişsel Yapılarının Kelime İlişkilendirme Testiyle İncelenmesi

Tablo 1. (devamı)

\begin{tabular}{|c|c|c|c|c|c|c|}
\hline \multirow[t]{2}{*}{ Yanıt Kelimeler } & \multicolumn{6}{|c|}{ Anahtar Kavramlar } \\
\hline & 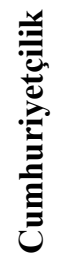 & 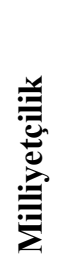 & 尖 & 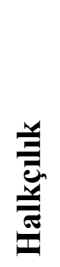 & 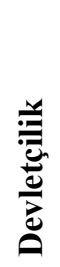 & 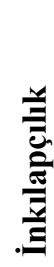 \\
\hline Cep telefonu & & & & & 2 & 14 \\
\hline Televizyon & & & & & & 4 \\
\hline Tarih & & 4 & & & & 6 \\
\hline Uygarlik & 4 & & & & & \\
\hline Gençliğe Hitabe & 6 & 6 & & 2 & 2 & \\
\hline İstiklal Marşı & 6 & 10 & & 2 & 4 & 2 \\
\hline Atatürk & 5 & 2 & & 2 & & 8 \\
\hline Kültür & & 10 & 4 & & 2 & \\
\hline Sevgi & & & & 2 & & \\
\hline Çağdaşlık & 2 & 2 & 8 & & 4 & 4 \\
\hline Siyaset & & & & & 2 & 4 \\
\hline Köprü & & & & & 2 & \\
\hline Mahkeme & & & & & 2 & \\
\hline Yol & & & & & 4 & \\
\hline Alfabe & & 2 & & & & 8 \\
\hline Bilgisayar & & & & & 2 & 18 \\
\hline Kızların erken yaşta evlenmemesi & 2 & & & & & \\
\hline Hukuk & & 2 & & 2 & & \\
\hline Yasama, yürütme ve yarg1 & 2 & & 2 & 2 & 2 & 2 \\
\hline Hükümet & 2 & & & 2 & & 2 \\
\hline Siyasi partiler & 2 & & & & & \\
\hline Halife & 2 & & & & & \\
\hline Padişah & 2 & & & & & \\
\hline Muhtar & 4 & & & & & \\
\hline Aza & 2 & & & 2 & & \\
\hline TBMM & 12 & 8 & & & & 2 \\
\hline Türk dili & & 10 & & & & \\
\hline Kadinlar & & & 2 & 2 & & \\
\hline Belediye & & & & & 2 & \\
\hline Çöpçü & & & & & 2 & \\
\hline Topluma hizmet & & & & 2 & & \\
\hline Kanunların üstünlüğü & & & & 2 & & \\
\hline Vicdan & & & 2 & & & \\
\hline Klasik müzik & & & & & & 8 \\
\hline 1923 & 6 & & & & & \\
\hline Ülke & & & & & 2 & \\
\hline Oy sandiğ 1 & 4 & & & 4 & & \\
\hline Kapitülasyon & & & & & 2 & \\
\hline Yatırım & & & & & & 2 \\
\hline Vatandaş & 2 & & 2 & & 2 & 2 \\
\hline
\end{tabular}


Tablo 1 incelendiğinde anahtar kavramlara (Atatürk ilkeleri) ilişkin en çok tekrarlanan kelimelerin boyandığı; ayrıca Atatürk ilkelerine yönelik toplam 103 kelimenin üretildiği görülmektedir. Bunlardan;

$>$ Cumhuriyetçilik ilkesine yönelik en çok tekrarlanan kelime, seçme-seçilme ( $\mathrm{f}=32)$,

> Milliyetçilik ilkesine yönelik en çok tekrarlanan kelime, millet ve Türk ( $\mathrm{f}=28)$,

$>$ Laiklik ilkesine yönelik en çok tekrarlanan kelime, din $(\mathrm{f}=41)$,

> Halkçılık ilkesine yönelik en çok tekrarlanan kelime, eşitlik ( $\mathrm{f}=48$ ),

$>$ Devletçilik ilkesine yönelik en çok tekrarlanan kelime, fabrika ve ekonomi ( $\mathrm{f}=34)$,

$>$ İnkılapçl1ık ilkesine yönelik en çok tekrarlanan kelime, yenilik ( $\mathrm{f}=48)$ olmuştur.

Tablo 1'deki frekans tablosuna uygun olarak oluşturulan ve öğrencilerin bilişsel yapısını gösteren kavram ağı şekiller aracılığıyla gösterilmiştir. Bu amaçla kesme noktası 40 ve yukarısına ilişkin oluşturulan kavram ağı Şekil 1'de sunulmuştur:
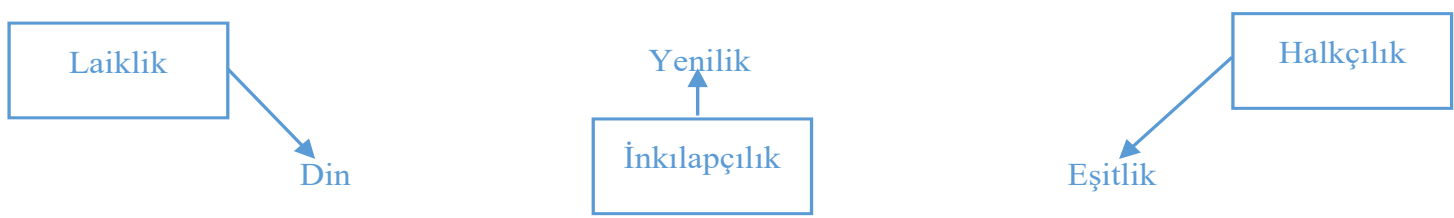

Kesme noktası 40 ve yukarıs1

Şekil 1: Kesme Noktası 40 ve Yukarısı İçin Oluşturulan Kavram Ağ1

Kesme noktası 40 ve yukarısı: Şekil 1 incelendiğinde, bu aralıkta öğrencilerin Laiklik ilkesi ile din kavramını, Halkçılık ilkesi ile eşitlik kavramını ve İnkılapçılık ilkesiyle de yenilik kavramını ilişkilendirdikleri görülmektedir. Buna ek olarak kavramların birbirinden kopuk ve ilişkisiz bir yapıda olduğu söylenebilir.

Kesme noktası 30-39 arasında oluşturulan kavram ağı Şekil 2'de gösterilmiştir:
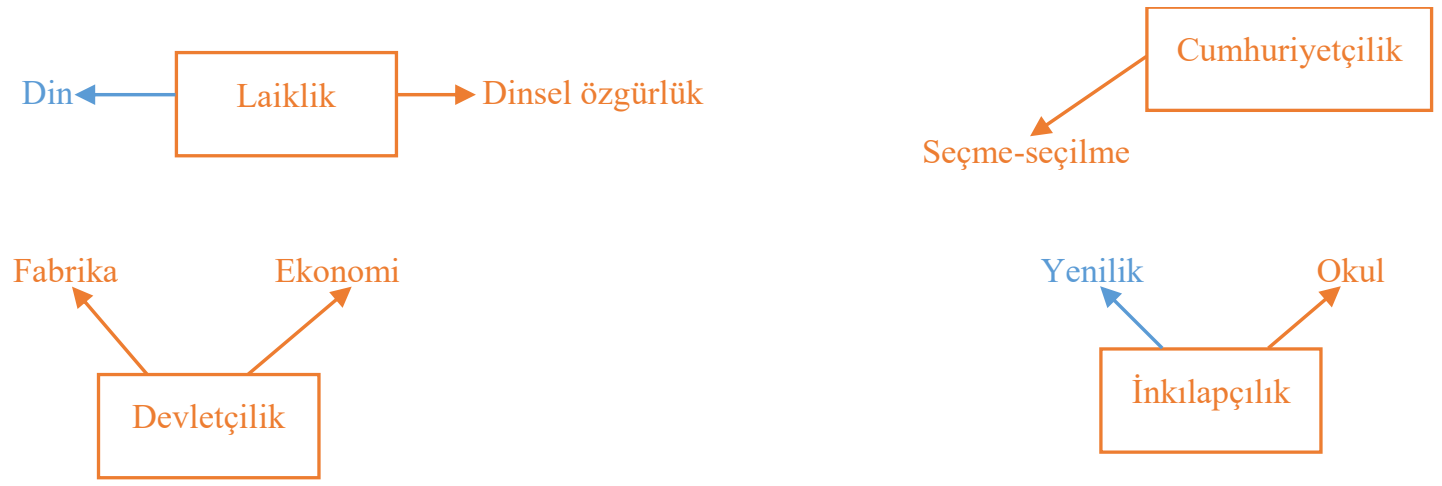

Kesme noktas1 30-39 aras1

Şekil 2: Kesme Noktas1 30-39 Arası Oluşturulan Kavram Ağ1 
Sekizinci Sınıf Öğrencilerinin Atatürk İlkelerine Yönelik Bilişsel Yapılarının Kelime İlişkilendirme Testiyle İncelenmesi

Kesme noktası 30-39 arası: Şekil 2 incelendiğinde bu aralıkta öğrencilerin, Laiklik ilkesi ile dinsel özgürlük kavramını, Cumhuriyetçilik ilkesi ile seçme-seçilme kavramını, Devletçilik ilkesiyle fabrika ile ekonomi kavramlarını ve İnkılapçılık ilkesiyle de okul kavramını ilişkilendirdikleri görülmektedir. Buna ek olarak kavramların birbirinden kopuk ve ilişkisiz bir yapıda olduğu söylenebilir.

Kesme noktası 20-29 arasında oluşturulan kavram ağı Şekil 3'te gösterilmiştir:
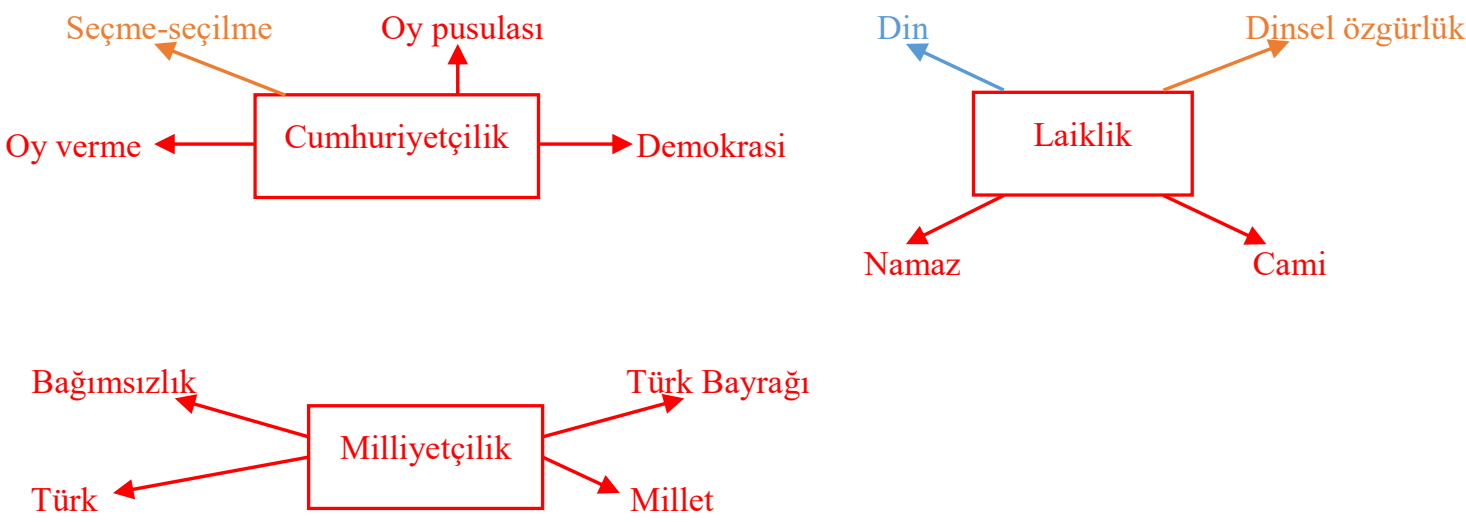

Şekil 3: Kesme Noktas1 20-29 Arası Oluşturulan Kavram A $\breve{g} 1$

Kesme noktası 20-29 arası: Şekil 3 incelendiğinde bu aralıkta öğrencilerin, Laiklik ilkesini namaz ve cami; Cumhuriyetçilik ilkesini oy verme, oy pusulası ve demokrasi ve Milliyetçilik ilkesini de bağımsızlık, Türk Bayrağı, Türk ve millet kavramlarıyla ilişkilendirdikleri görülmektedir. Buna ek olarak kavramların birbirinden kopuk ve ilişkisiz bir yapıda olduğu söylenebilir.

Kesme noktası 10-19 arasında oluşturulan kavram ağı Şekil 4'te gösterilmiştir: 


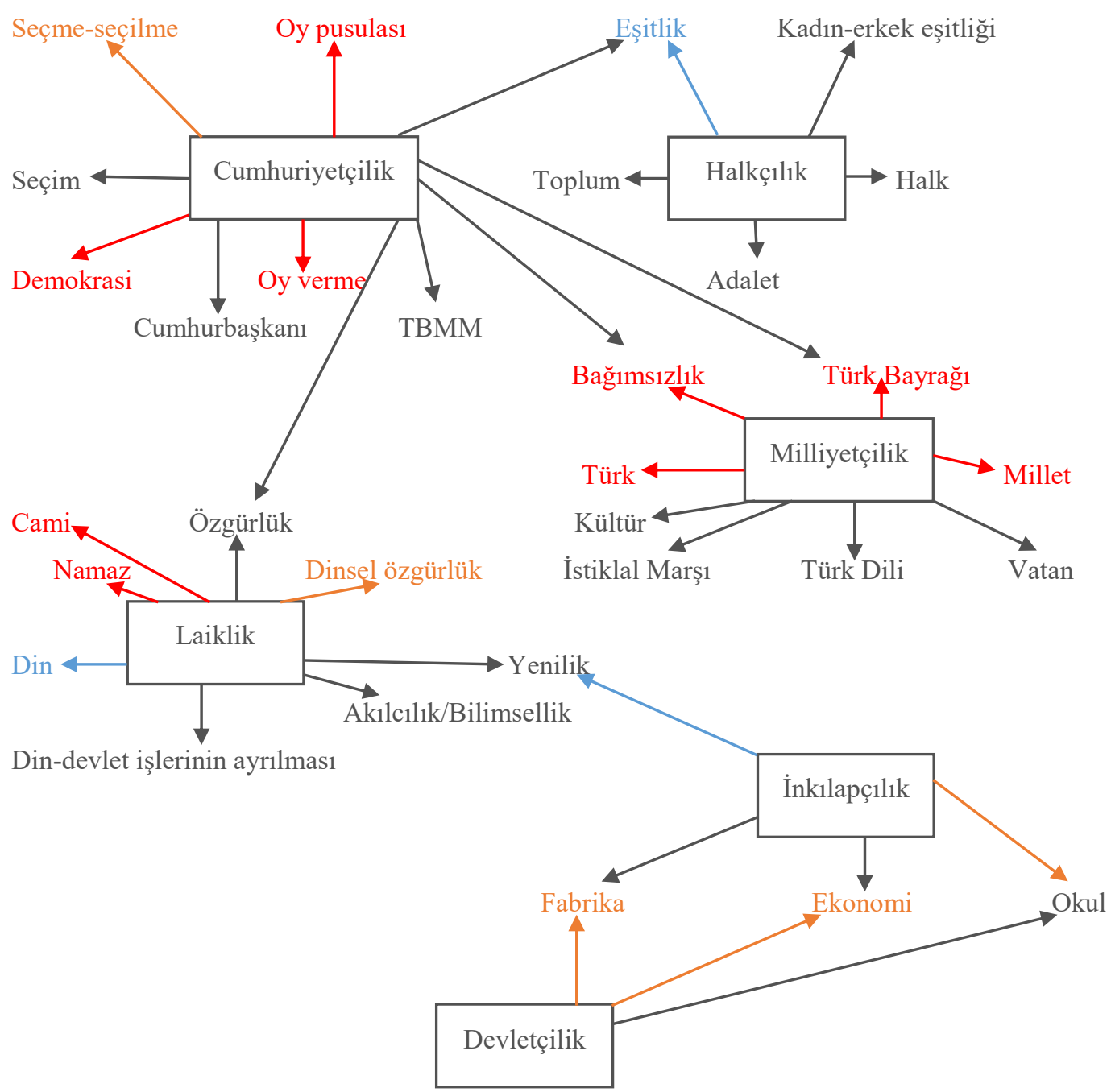

Şekil 4: Kesme Noktası 10-19 Arası İçin Oluşturulan Kavram Ağ1

Kesme noktası 10-19 arası: Şekil 4 incelendiğinde, bu aralıkta öğrencilerin, Atatürk ilkeleri için ürettikleri kelimelere ilişkin bütün kavram ağı görülmektedir. Bu aralıkta ilk kez kavramlar arası ilişkilendirmeler de başlamıştır. Başka bir anlatımla bu aralıkta ilkeler temelinde kavramlar arasında kurulan bazı ilişkilendirmelerin, önceki kesme noktalarında ortaya çıkmadığ söylenebilir. Bu bağlamda;

D Eşitlik kavramı ile Cumhuriyetçilik ve Halkçıllk,

$>$ Yenilik kavramıyla İnkılapçılık ve Laiklik,

Fabrika, ekonomi ve okul kavramlarıyla Devletçilik ve İnkılapçılık,

> Bağımsızlık ve Türk Bayrağı kavramlarıyla Milliyetçilik ve Cumhuriyetçilik,

$>$ Özgürlük kavramıla Laiklik ve Cumhuriyetçilik ilkelerinin ilişkilendirildiği görülmüştür.

Öğrencilerin Atatürk ilkelerine yönelik kurdukları cümleler ise ilkelerle ilişkisi gözetilerek çözümlenmiştir. Çözümleme sonucunda cümleler, bilimsel bilgi ve kavram yanılgısı içeren 
Sekizinci Sınıf Öğrencilerinin Atatürk İlkelerine Yönelik Bilişsel Yapılarının Kelime İlişkilendirme Testiyle İncelenmesi

cümleler ile boş bırakılan cümleler şeklinde gruplara ayrılarak incelenmiştir. Buna ilişkin siniflandırma sistemi Tablo 2'de sunulmuştur:

Tablo 2. Atatürk İlkelerine Yönelik Bilimsel Bilgi ile Kavram Yanılgısı İçeren ve Boş Bırakılan Cümle Sayıları

\begin{tabular}{lccc}
\hline Anahtar kavram (ilke) & $\begin{array}{c}\text { Bilimsel bilgi içeren } \\
\text { cümle sayısı }\end{array}$ & $\begin{array}{c}\text { Kavram yanılgısı } \\
\text { içeren cümle sayısı }\end{array}$ & $\begin{array}{c}\text { Boş bırakılan cümle } \\
\text { sayısı }\end{array}$ \\
\hline Cumhuriyetçilik & 68 & 4 & 16 \\
\hline Milliyetçilik & 44 & 16 & 28 \\
\hline Laiklik & 40 & 36 & 12 \\
\hline Halkçılık & 40 & 28 & 20 \\
\hline Devletçilik & 36 & 24 & 28 \\
\hline İnkılapçılık & 28 & 32 & 28 \\
\hline
\end{tabular}

Tablo 2 incelendiğinde öğrencilerin çoğunluğunun Atatürk ilkeleriyle ilgili cümle kurdukları görülmektedir. En sık olarak da Cumhuriyetçilik ilkesine ilişkin cümleler kurulduğu $(f=72)$ söylenebilir. İlgili cümleler, bilimsel bilgi ve kavram yanılgısı içeren cümleler şeklinde incelendiğinde ise, en çok Cumhuriyetçilik ilkesinin bilimsel tanımına uygun olarak kullanıldığı, buna karşılık en çok Laiklik ilkesi ile ilgili kurulan cümlelerin kavram yanılgısı içerdiği belirlenmiştir. Buna ek olarak öğrencilerin en çok Milliyetçilik, Devletçilik ve İnkılapçılık ilkeleriyle ilgili cümle kuramadıkları görülmektedir.

Cumhuriyetçilikle ilgili kurulan cümleler: Öğrencilerin, Cumhuriyetçilik ilkesiyle ilgili kurdukları, "Geçen hafta Cumhuriyetçilik ilkesi gereği seçim yaptık.", "Cumhuriyetçilik demokrasiyi esas alır.", "Cumhuriyette çok partili siyasi hayat vardır.", "Cumhuriyet; yani demokrasi, seçme-seçilme hakkı iyi ki gelmiş.", "Cumhuriyetçilik, devlet yönetimine halkın sahip olmasıdır." ve "Cumhuriyetçilikte halk, kendini yönetecek kișiyi seçer." șeklindeki ifadeler, bilimsel bilgi içeren cümlelere örnek olarak verilebilir. Öğrencilerin Cumhuriyetçilikle ilgili kurdukları cümlelerde genellikle seçme ve seçilme olgusuna vurgu yaptıkları söylenebilir. Öte yandan öğrencilerin Cumhuriyetçilik ilkesiyle ilgili kurdukları, "Cumhuriyet medeniyet demektir. Medeniyet dediğin tek kişi kalmış canavardır." ve "Cumhuriyet, İstiklal Marşı'mızın bir kıtasıdır." şeklindeki cümleler kavram yanılgısı içeren cümlelere örnek olarak verilebilir.

Milliyetçilikle ilgili kurulan cümleler: Öğrencilerin, Milliyetçilik ilkesiyle ilgili kurdukları, "Türkçülük önemlidir.", "Atatürk sayesinde bağımsız bir devlet olduk.", "Ne mutlu Türk'üm diyene!", "Milliyetçilik, bağımsızlığı esas alır.", "Milliyetçilik, vatan ve milletle alakalı bir kelimelidir. Yani Milliyetçilik, birlik ve beraberlik demektir." ve "Milliyetçilik, Türk dili ve kültürüne sahip çıkmak vs. dir." şeklindeki ifadeler, bilimsel bilgi içeren cümlelere örnek olarak verilebilir. Öte yandan öğrencilerin Milliyetçilik ilkesiyle ilgili kurdukları, "Milliyetçilik vatandaşlar için vardır." ve "Milliyetçilik herkesin istediğini yapmakta özgür olmasıdır." şeklindeki cümleler, kavram yanılgısı içeren cümlelere örnek olarak verilebilir.

Laiklikle ilgili kurulan cümleler: Öğrencilerin, Laiklik ilkesiyle ilgili kurdukları, "Herkes istediği dini yaşayabilir.", "İnsanların kendi dini inançlarını istedikleri gibi yaşamalarıdır.", "Herkes kendi dinini seçmekte özgürdür." ve "Laiklik, din ve devlet işlerinin ayrımıdır. Laiklik olmasaydı din ile devlet ayrılamaz ve devletinde bir dini olmak zorunda kalırdı." șeklindeki ifadeler, bilimsel bilgi içeren cümlelere örnek olarak verilebilir. Öğrencilerin Laiklikle ilgili kurdukları cümlelerde genellikle dinsel özgürlük olgusuna vurgu yaptıkları söylenebilir. Öte yandan öğrencilerin Laiklik ilkesiyle ilgili kurduğu, "Her insan namaz k1lmalı.", "Din kurallarına göre hareket etmektir.", "Bir yer, Cami gibi...", "Devletimize sahip çıkmalıyız. Laiklik kısaca din ve mezhep demektir. Buna örnek namaz, oruç olabilir; yani din devleti." ve 
"Laiklik yenilik demektir. Ülkemizde yenilikler yapıldı." şeklindeki cümleler, kavram yanılgısı içeren cümlelere örnek olarak verilebilir.

Halkçılıkla ilgili kurulan cümleler: Öğrencilerin, Halkçılık ilkesiyle ilgili kurdukları, "Toplumda herkese eşit davranmalıyız.", "Kanun önünde herkes eşittir.", "Bana göre çok adaletli bir devletiz.", "Halkçılık sayesinde herkese eşit davranıldı.", "Halkçılık kısaca eşitlik demektir." ve "Bu yılda emeklilere yardım edildi." şeklindeki ifadeler, bilimsel bilgi içeren cümlelere örnek olarak verilebilir. Öğrencilerin Halkçllıkla ilgili kurdukları cümlelerde genellikle eşitlik olgusuna vurgu yaptıkları söylenebilir. Öte yandan öğrencilerin Halkçılık ilkesiyle ilgili kurduğu, "Herkes oy kullanabilir de, kullanmayabilir de.", "Halkın birlik ve beraberlik ile çözemeyeceği sorun yoktur.", "Halkın seçimidir." ve "Ünlüler hakkındadır." şeklindeki cümleler, kavram yanılgısı içeren cümlelere örnek olarak verilebilir.

Devletçilikle ilgili kurulan cümleler: Öğrencilerin, Devletçilik ilkesiyle ilgili kurdukları, "Devletin ekonomiye katkı sağlamasıdır.", "Devletimiz bu yıl iplik fabrikası açtı.", "Devletçilik, devletin ekonomide söz sahibi olmasıdır." ve "Devletimiz sayesinde sanayi gelişti." şeklindeki ifadeler, bilimsel bilgi içeren cümlelere örnek olarak verilebilir. Öğrencilerin Devletçilikle ilgili kurdukları cümlelerde genellikle ekonomi olgusuna vurgu yaptıkları söylenebilir. Öte yandan öğrencilerin Devletçilik ilkesiyle ilgili kurduğu, "Kendimiz çabalayarak okumamız gerekir. Devletçilik kısaca devletle ilgilidir. Cumhurbaşkanı olabilir; ama adı üstünde devletle alakalı.", "Çağdaş bir ülke olma yolundayız.", "Dinimiz İslamdır." ve "Yenilik demektir. Devletimiz yeniliklerle doludur." şeklindeki ifadeler, kavram yanılgısı içeren cümlelere örnek olarak verilebilir.

Inkılapçılıkla ilgili kurulan cümleler: Öğrencilerin, İnk1lapçı1lı ilkesiyle ilgili kurdukları, "Atatürk yenilikler yaptı.", "Alfabe değişikliği yaptık.", "Üniversite reformu yaptık." ve "İnkılapçllık yenilik demektir." şeklindeki ifadeler, bilimsel bilgi içeren cümlelere örnek olarak verilebilir. Öğrencilerin İnkılapçllıkla ilgili kurdukları cümlelerde genellikle yenilik ve değişim olgularına vurgu yaptıkları söylenebilir. Öte yandan öğrencilerin İnkılapçılık ilkesiyle ilgili kurduğu, "Devlet istediğini yapar.", "Ekonomimizi geliştirmeliyiz. İnkılapçılık yatırımla; yani sanayi, ekonomiyle ilgili, fabrikalarla ilgilidir." ve "İnkılapçılık savaş hakkındadır. Ülkeler arasında savaş yapıldı." şeklindeki ifadeler, kavram yanılgısı içeren cümlelere örnek olarak verilebilir.

\section{Tartışma ve Sonuçlar}

Araştırmayla, 8. sınıf öğrencilerinin, Atatürk ilkelerine ilişkin bilişsel yapılarının KİT aracılığıyla ortaya çıkarılması amaçlanmıştır. Böylece öğrencilerin Atatürk ilkelerine yönelik bilişsel yapı ve kavram yanılgıları belirlenmeye çalışılmıştır.

Araştırmada öğrencilerin Cumhuriyetçilik ilkesiyle en çok seçme-seçilme kavramını ilişkilendirdikleri saptanmıştır. Ayrıca bu kavramı oy pusulası, oy verme ve demokrasi kavramlarının izlediği görülmüştür. $\mathrm{Bu}$ bağlamda öğrencilerin demokrasi kavramı ile Cumhuriyetçilik ilkesi arasında bir ilişki kurdukları ve bu ilişkinin Cumhuriyetçilik ilkesinin bilimsel tanımına uygun olduğu söylenebilir. Çünkü Cumhuriyetçilik, başta devlet başkanı olmak üzere devletin temel organlarında görev alan kimselerin seçim ilkesine göre belirlendiği bir yönetim biçimidir (Diker, 2011). Bu yönüyle de demokrasiyle yönetilen devlet demektir (Afetinan, 1969). Benzer şekilde Işıklı ve diğerleri (2011) tarafından yapılan çalışmada, Cumhuriyetçilik ilkesi ile en çok ilişkilendirilen kavramın demokrasi olduğu saptanmıştır. Buna parelel olarak Er Tuna (2018) ile Akman ve Koçoğlu (2016) tarafından yapılan çalışmalarda da, Cumhuriyetçilik ilkesi ile en çok ilişkilendirilen kavramların seçim ve demokrasi olduğu belirlenmiştir. Bunların aksine İnel ve diğerleri (2016) tarafından yapılan çalışmada, 
Sekizinci Sınıf Öğrencilerinin Atatürk İlkelerine Yönelik Bilişsel Yapılarının Kelime İlişkilendirme Testiyle İncelenmesi

cumhuriyetçilik ile en çok ilişkilendirilen kavramın Atatürk olduğu; aynı zamanda demokrasi ile de en çok eşitlik ve özgürlük kavramlarının ilişkilendirildiği tespit edilmiştir.

Araştırmada öğrencilerin Milliyetçilik ilkesiyle en çok millet ve Türk kavramlarını ilişkilendirdikleri saptanmıştır. Dolayısıyla öğrencilerin Türk milleti kavramı ile Milliyetçilik ilkesi arasında bir ilişki kurdukları söylenebilir. Öğrencilerin milliyetçilik ile ilgili kurdukları cümleler incelendiğinde ise, milliyetçilik ile ırkçılık kavramları arasında hiçbir ilişki kurmadıkları ve birlik/beraberlik, bağımsızlık ile kültürü ön plana çıkardıkları görülmüştür. Çelebi'ye (2007) göre barış̧̧ıl özellikler taşıyan Atatürk milliyetçiliği, milli birlik ile beraberliği esas almakta ve ırkçılığı reddetmektedir. Bu bağlamda öğrencilerin milliyetçilik anlayışlarının barışçıl özellikler taşıdığı söylenebilir. Buna koşut olarak Er Tuna (2018) tarafından yapılan çalışmada, Milliyetçilik ilkesi ile en çok ilişkilendirilen kavramların millet ve birlik/beraberlik olduğu belirlenmiştir. Bunun aksine Akman ve Koçoğlu (2016) tarafindan yapılan çalışmada, Milliyetçilik ilkesinin bağımsızlık ve milli kültür kavramlarının yanı sıra ırkçılık kavramıyla da ilişkilendirildiği tespit edilmiştir. Benzer şekilde Işıklı ve diğerleri (2011) tarafından yapılan çalışmada da, Milliyetçilik ilkesi ile en çok ilişkilendirilen kavramlar millet ile Türk olsa da, öğrencilerin milliyetçiliği tanımlarken ırkçılık kavramını da kullandıkları saptanmıştır.

Araştırmada öğrencilerin Laiklik ilkesiyle en çok din ve dinsel özgürlük kavramlarını ilişkilendirdikleri saptanmıştır. Dolayısıyla öğrencilerin din kavramı ile Laiklik ilkesi arasında bir ilişki kurdukları söylenebilir. Bu durum öğrencilerin laiklik ilkesini dinsel özgürlükle ilişkilendirdikleri için kavramı bilimsel tanımına uygun olarak kullandıkları; öte yandan din ile ilişkilendirdikleri için de kavram yanılgılarına sahip olduklarını göstermektedir. Bu bağlamda öğrencilerin Laiklik ilkesi ile ilgili birbirine zit bağlantılar kurdukları sonucuna ulaşılmıştır. Benzer şekilde yapılan çalışmalarda da Laiklik ilkesi ile din kavramının ilişkilendirildiği saptanmıştır (Akman \& Koçoğlu, 2016; Er Tuna, 2018; Işıklı vd., 2011).

Araştırmada öğrencilerin Halkçlık ilkesiyle en çok eşitlik kavramını ilişkilendirdikleri belirlenmiş̧ir. Aynı zamanda öğrencilerin halkçılık ile ilgili kurdukları cümleler incelendiğinde, onların ekonomik, siyasal ve sosyal adaleti vurguladıkları görülmektedir. Bu bağlamda öğrencilerin sınıf mücadelesini reddeden ve sosyal dayanışmayı gerçekleştirmeyi sağlayan bir halkçılık anlayışına sahip oldukları sonucuna ulaşılmıştır. Benzer şekilde yapılan çalışmalarda da Halkçılık ilkesi ile eşitlik kavramının ilişsilendirildiği (Er Tuna, 2018; Işıklı vd., 2011); ancak sosyal adaletin vurgulanmadığı tespit edilmiştir. Öte yandan Bahar ve Kılıç (2001) tarafından yapılan çalışmada, öğrencilerin Halkçılık ilkesiyle en çok toplum kavramını ilişkilendirdikleri belirlenmiştir.

Araştırmada öğrencilerin Devletçilik ilkesiyle en çok fabrika ve ekonomi kavramlarını ilişkilendirdikleri saptanmıştır. Bu durum öğrencilerin Devletçilik ilkesi ile ekonomik kavramlar arasında bir ilişki kurdukları ve devletçiliği dar anlamda da olsa bilimsel tanımına uygun olarak kullandıkları şeklinde yorumlanabilir. Çünkü dar anlamda devletçilik, iktisadi devletçilik şeklinde tanımlanmaktadır. İktisadi devletçilikte devlet, ekonomik alana doğrudan müdahale etmekte, bunun bir sonucu olarak ülkenin ekonomik olarak kalkınması için özel sektörün yetersiz kaldığ devletçilik ile ekonomik kalkınma arasında bağlantı kurdukları sonucuna ulaşılmıştır. Benzer şekilde yapılan çalışmalarda da Devletçilik ilkesiyle ekonomi ve bununla ilgili kavramların (para, sermaye gibi) ilişkilendirildiği saptanmıştır (Akman \& Koçoğlu, 2016; Er Tuna, 2018; Işıklı vd., 2011).

Araştırmada öğrencilerin İnkılapçılık ilkesiyle en çok yenilik kavramını ilişkilendirdikleri belirlenmiştir. Bunu, öğrencilerin belli bir inkılap bağlamında yapılan (örnek Şapka Kanunu ile 
kılık ve kıyafetteki değişiklik) yenilikler olarak anladıkları söylenebilir. Bu bağlamda öğrencilerin İnkılapçılık ilkesini yalnızca toplumsal alanda yapılan devrimler olarak anladıkları sonucuna ulaşılmıştır. Benzer şekilde Akman ve Koçoğlu (2016) tarafından çalışmada da öğrencilerin inkılapçılığı Şapka Kanunu ve kılık-kıyafetteki yenilikler şeklinde anladıkları tespit edilmiştir. Ancak öğrencilerin bir kısmının inkılapçılığı bilişim teknolojilerindeki yenilik olarak da algıladıkları belirlenmiştir. Çünkü öğrencilerin inkılapçılıkla ilgili cümleleri incelendiğinde, akı1lı telefon ve bilgisayar kavramları bağlamında inkılapçılıkla ilgili cümleler kurdukları görülmüştür. Benzer şekilde yapılan çalışmalarda da İnkılapçılık ilkesi ile yenilik kavramının ilişkilendirildiği saptanmıştır (Bahar \& Kılıç, 2001; Er Tuna, 2018; Işıklı vd., 2011).

Öğrencilerin bilişsel yapısında Cumhuriyetçilik, Halkçılık, Milliyetçilik ve Laiklik ilkelerinin kendi aralarında ilişkili olduğu ve bütüncül bir kavram ağı oluşturabilecek biçimde bir arada bulunduğu belirlenmiştir. Atatürk ilkelerinin birbirini tamamlayan ve birbiriyle ilişkili olan özellikleri göz önünde bulundurulduğunda, öğrencilerin bilişsel yapısında, ilkelerin örgütlenmiş bir bütünün çeşitli parçaları olarak yer alması, Atatürk ilkelerinin büyük oranda doğru olarak algılandığını göstermektedir. Ancak Devletçilik ve İnkılapçılık ilkelerinin diğer ilkelerle daha az oranda ilişkilendirildikleri söylenebilir. Bu durum Devletçilik ve İnkılapçılık ilkelerinin öğrencilerin bilişsel yapılarında, diğer Atatürk ilkelerinden kopuk bir şekilde algılandığı şeklinde yorumlanabilir. Ayrıca öğrencilerin Atatürk'ün temel ve bütünleyici ilkelerini bütünsel olarak algıladıkları söylenebilir. Çünkü öğrencilerin bilişsel yapısını ortaya çıkarmak için oluşturulan kavram ağında, öğrencilerin Atatürk'ün altı temel ilkesiyle bütünleyici ilkelerini (bağımsızlık, özgürlük, akılcılık ve bilimsellik gibi) ilişkilendirdikleri tespit edilmiştir.

Öğrencilerin, kavram yanılgıları incelendiğinde, ilkelerle ilgili bazı yanlış ilişkilendirmeler yaptıkları saptanmıştır. Bu bağlamda öğrencilerin İnkılapçılık ilkesiyle okul ile fabrika, Laiklik ilkesiyle namaz ile cami, Cumhuriyetçilik ilkesiyle bağımsızlık ile Türk Bayrağı ve Devletçilik ilkesiyle okul kavramlarını yanlış bir şekilde ilişkilendirdikleri belirlenmiştir. Bunların yanı sıra öğrencilerin en çok Laiklik ve İnkılapçılık ilkelerine ilişkin kavram yanılgısına sahip oldukları, devletçilik ve inkılapçılık kavramlarını birbirinin yerine kullandıkları ve sonuç olarak bu kavramlara yönelik kafa karışıklığı yaşadıkları söylenebilir. Bununla bağlantı olarak öğrencilerin en çok ekonomi ve yenilik gibi kavramları hem Devletçilik hem de İnkılapçılık ilkelerine yönelik olarak kullandıkları saptanmıştır. Ayrıca öğrencilerin cümle sayıları incelendiğinde, öğrencilerin en çok Milliyetçilik, Devletçilik ve İnkılapçılık ilkelerine ilişkin cümle kuramadıkları görülmüştür. Ercan, Taşdere ve Ercan'a (2010) göre boş bırakılan veya anahtar kavramlara dayalı anlamlı bir cümle kurulamaması, öğrencilerin bu kavramları anlamlı bir şekilde ve kavramsal olarak öğrenemediğini gösterebilir. Bu bağlamda boş bırakılan ilgili cümleler için öğrencilerin bilimsel ve kavramsal düzeyde bilgiye sahip olmadıkları savunulabilir.

Araştırmanın sonuçlarından birkaç öncelikli çıkarım yapılabilir. Öncelikle ilkelere verilen yanıt kelimeler incelendiğinde, ortaokul öğrencilerinin Atatürk'ten bağımsız ve kopuk bir şekilde Atatürk ilkelerini algılamaya çalıştıkları söylenebilir. İkinci olarak öğrencilerin Devletçilik ve İnkılapçılık ilkelerini ortak kavramlar aracılı̆̆ıyla anladıkları düşünülmektedir. Üçüncü olarak Laiklik ilkesiyle ilgili kavram yanılgılarının temelinde dinsel devlet algısının olduğu söylenebilir.

Bulgulara dayalı olarak;

$\checkmark$ Ortaokul öğrencilerinin özellikle Laiklik ve İnkılapçılık ilkeleriyle ilgili kavram yanılgılarının erken yaşlarda önlenmesi için öğretim etkinliklerinin düzenlenmesi,

$\checkmark$ Sosyal bilgiler öğretmenlerinin Devletçilik ve İnkılapçılık ilkelerine yönelik ders planlarına örnek olan ve olmayan durumları dâhil etmeleri, 
$\checkmark \quad$ T.C. İnkılap Tarihi ve Atatürkçülük dersine ilişkin öğrencilerin bilişsel yapı ve kavram yanılgılarını tespit etmek amacıyla başka çalışmaların yapılması,

$\checkmark$ KİT'in, deneysel bir desende kullanılarak, Atatürk ilkeleri bağlamında öğrencilerin kavramsal değişimlerinin incelenmesi önerilebilir.

\section{Kaynaklar}

Afetinan, A. (1969). Medeni bilgiler ve Mustafa Kemal Atatürk'ün el yazıları. Ankara: Türk Tarih Kurumu Yayınları.

Akman, O., \& Koçoğlu, E. (2016). Investigation 8th grade students secondary school cognitive structure about princeples of Ataturk through word association test. Journal of Education and Training Studies, 4(11), 151-160.

Atasoy, B. (2004). Fen öğrenimi ve ögrretimi. Ankara: Asil yayıncılık.

Bahar, M., Johnstone, A. H., \& Sutcliffe, R. G. (1999). Investigation of students' cognitive structure in elementary genetics through word association tests. Journal of Biological Education, 33, 134-141.

Bahar, M., \& Kılıç, F. (2001). Kelime iletişim testi yöntemi ile Atatürk ilkeleri arasındaki kavramsal bağların araştırılması. X. Ulusal Eğitim Bilimleri Kongresi, Bolu.

Bahar, M., \& Özatlı, N. S. (2003). Kelime ilişkilendirme yöntemi ile lise 1. sınıf öğrencilerinin canlıların temel bileşenleri konusundaki bilişsel yapılarının araştırılması. Balıkesir Üniversitesi Fen Bilimleri Enstitüsü Dergisi, 5(1), 75-85.

Candan, A. S. (2009). Tarih ögrretim yöntemleri. M. Demirel \& İ. Turan (Ed.). Ankara: Nobel.

Cohen, L., \& Manion, L. (1998). Research methods in education. London: Routledge.

Çelebi, M. (2007). Türk inkılap tarihi. İstanbul: Özal Matbaası.

Deveci, H., Çengelci Köse, T., \& Gürdoğan Bayır, Ö. (2014). Öğretmen adaylarının sosyal bilimler ve sosyal bilgiler kavramlarına ilişkin bilişsel yapıları: Kelime ilişkilendirme testi uygulamas1. Adiyaman Üniversitesi Sosyal Bilimler Enstitüsü Dergisi, 7(16), 101124.

Diker, H. (2011). Türk inkılabının dayandığı temel ilkeler. İçinde C. Öztürk (Ed.), Imparatorluktan ulus devlete Türk inkalap tarihi (s. 310-327). Ankara: Pegem Akademi.

Dinç, E., Sezer, A., Üztemur, S., \& İnel, Y. (2018). Ortaokul öğrencilerinin demokratik değerlere ilişkin bilişsel yapılarının kelime ilişkilendirme testi aracılığıyla incelenmesi. 2. Uluslararası Sosyal Bilimler Eğitimi Sempozyumu, Çanakkale.

Er Tuna, Y. (2018). Tarih ve sosyal bilgiler öğretmen adaylarının Atatürk ilkelerine ilişkin bilişsel yapılarının kelime ilişkilendirme testi aracılığ 1 ile belirlenmesi. Turkish History Education Journal, 7(1), 43-68.

Ercan, F., Taşdere, A., \& Ercan, N. (2010). Kelime ilişskilendirme testi aracılığıyla bilişsel yapının ve kavramsal değişimin gözlenmesi. Türk Fen Eğitimi Dergisi, 7(2), 136-154.

Ezer, F., Ulukaya, Ü., \& Kaçar, T. (2016). İlköğretim 6. sınıf öğrencilerinin Türkiye Cumhuriyeti İnkılap Tarihi ve Atatürkçülük dersine yönelik tutumları. Kilis 7 Aralık Üniversitesi Sosyal Bilimler Dergisi, 6(11), 71-91.

Fraenkel, J. R., \& Wallen, N. E. (2006). How to design and evaluate research in education. New York: McGraw-Hill International Edition. 
Glesne, C. (2015). Nitel araştırmaya giriş (Çev: A. Ersoy \& P. Yalçınoğlu). Ankara: Anı Yayınc1lik.

Goldstein, E. B. (2013). Bilişsel psikoloji (Çev: O. Gündüz). İstanbul: Kaknüs Yayınları.

Güneş, B. (2006). Bilimsel hatalar ve kavram yanılgıları. İçinde R. Yağbasan \& B. Güneş (Ed.), Konu alanı ders kitabı inceleme kılavuzu. Ankara: Gazi Kitabevi.

Işıklı, M., Taşdere, A., \& Göz, N. L. (2011). Kelime ilişkilendirme testi aracılığıyla öğretmen adaylarının Atatürk ilkelerine yönelik bilişsel yapılarının incelenmesi. Uşak Üniversitesi Sosyal Bilimler Dergisi, 4(1), 50-72.

İnel, Y., Akar, C., \& Üztemur, S. S. (2016). Ortaokul 8. sınıf öğrencilerinin yönetim biçimleri kavramlarına yönelik algılarının kelime ilişkilendirme testi aracılığıyla tespiti. Tarih Okulu Dergisi, 9(28), 523-540.

Jadallah, E. (2000). Constructivist learning experiences for social studies education. The Social Studies, 91, 221-225.

Karasar, N. (2017). Bilimsel araştırma yöntemi. Ankara: Nobel.

McClelland, J. L., \& Rogers, T. T. (2003). The parallel-distributed processing approach to semantic cognition. Nature Reviews Neuroscience, 4, 310-322.

Milli Eğitim Bakanlığı (MEB). (2018). Ortaokul T.C. Inkllap Tarihi ve Atatürkçülük Dersi Ögretim Programı. Ankara: Talim ve Terbiye Kurulu Başkanlığı.

Karakuş, U. (2019). Sosyal bilgiler öğretmen adaylarının doğal afet kavramlarına ilişkin algılarının kelime ilişkilendirme testi aracılığıyla incelenmesi. Cumhuriyet International Journal of Education, 8(3), 735-751.

Öztaş, S., \& Kılıç, B. (2017). Atatürk İlkeleri ve İnkılap Tarihi Dersi'nin uzaktan eğitim şeklinde verilmesinin üniversite öğrencilerinin görüşleri açısından değerlendirilmesi (Kırklareli Üniversitesi Örneği). Turkish History Education Journal, 6(2), 268-293.

Öztürk, T., \& Yılmaz Özcan, N. (2017). Sosyal Bilgiler dersi “Bölgemizi Tanıyalım” ünitesinde öğrencilerin kavramsal gelişim sürecinin incelenmesi. PAU Eğitim Fakültesi Dergisi, 42, 109-123.

Rogers, T. T., \& McClelland, J. L. (2004). Semantic cognition: A parallel distributed processing approach. Cambridge, MA: MIT Press.

Sabanc1, O. (2008). İlköğretim 7. sinıf öğrencilerinin Sosyal Bilgiler dersinde yer alan vatandaşlık konularıyla ilgili kavramsal algıları (Yayımlanmamış yüksek lisans tezi). Gazi Üniversitesi Eğitim Bilimleri Enstitüsü, Ankara.

Ülgen, G. (2004). Kavram geliştirme. Ankara: Nobel.

Yakışan, M., Selvi, M., \& Yürük, N. (2007). Biyoloji öğretmen adaylarının tohumlu bitkiler hakkındaki alternatif kavramları. Türk Fen Eğitimi Dergisi, 4(1), 60-79.

\section{EXTENDED ABSTRACT}

\section{Introduction}

It is seen that there are seven units in the T.R. History of Revolution and Kemalism Course Curriculum (2018) in middle school level. It can be said that the fourth unit of these is mainly devoted to Atatürk's principles. When Atatürk's principles are examined, it is determined that Atatürk's principles are built based on concepts. In the studies conducted, it has been determined 

Testiyle İncelenmesi

that the students have some fallacies and deficiencies with respect to the conceptual learning of the T.R. History of Revolution and Kemalism course.

Cognitive structures are formed as a result of the design of concepts in connecting networks (McClelland \& Rogers, 2003). In this context, different concepts and their characteristics can be represented in a network of connections. Therefore, in the connection network, concepts can come together in a relational way and present a visual of the concept in a cognitive structure (Goldstein, 2013). The learning process of the connection network should be in a way that includes concepts that are correctly defined relationally and scientifically. Otherwise, there may be misconceptions. Misconceptions can be explained in the form of mental models that work in harmony with other parts of meaning in the cognitive structure, that have supportive grounds underlying behind them and that are different from scientifically accepted views (Yakışan, Selvi \& Yürük, 2007).

is seen that many techniques are used to reveal cognitive structures. One of these techniques is the word association test (WAT). WAT is a technique that enables students to understand the cognitive structure and concept networks, and determines the adequacy of the relationships between concepts and information in long-term memory (Bahar \& Özatl1, 2003). Although there are many studies which had been conducted to determine the cognitive structures using WAT, it has been observed that the 8th grade students' misconceptions about the cognitive structure of Atatürk's principles and related principles could not be revealed through WAT.

\section{Purpose}

The aim of the study is to examine the cognitive structures of 8th grade students regarding Atatürk's principles through the Word Association Test. In this context, the sub-questions of the study are as follows: Regarding the 8th grade students;

a) How are their cognitive structures shaped related to Atatürk's principles?

b) What are the misconceptions about Atatürk's principles?

\section{Method}

The research was designed in accordance with the screening model. The study group of the research consisted of 100 students studying in the 8th grade from three public middle schools in a district of Sakarya in the 2019 year. In the research, as a data collection tool, WAT was used to reveal the cognitive structures of 8th grade students towards Atatürk's principles. In this research, Atatürk's principles were chosen as the concept; WAT approach has been established for this. Atatürk's principles (Republicanism, Nationalism, Secularism, Populism, Statism and Revolutionism) have been determined as key concepts in order to create the WAT. The relevant WAT is organized in two sections. In the first part, the gender information of 8th grade students and in the second part, concepts are included. The second part in which the concepts are included is as follows:

Secularism

Secularism

Secularism

Secularism

Secularism

Relevant Sentence 
Descriptive analysis was made on the data obtained through WAT.

\section{Findings}

It was determined that the principles of Republicanism, Populism, Nationalism and Secularism were interrelated in the cognitive structure of the students and were found together to form a holistic network. When the misconceptions of the students were examined, it was found that they made some wrong associations about the principles. In this context, it was determined that the students misrelated the concepts of school and factory with the principle of Revolutionism, prayer and mosque with the principle of secularism, independence with the principle of Republicanism and the Turkish flag and the principle of etatism. In addition to these, it can be said that students mostly have misconceptions about the principles of Secularism and Revolutionism, they use the concepts of statism and revolutionism interchangeably, and as a result, they experience confusion concerning these concepts.

It is seen that the majority of the students made sentences about Atatürk's principles. It can be said that most frequently sentences were made regarding the principle of Republicanism. When the related sentences were examined in the form of sentences containing scientific knowledge and misconceptions, it was determined that the principle of Republicanism was used in accordance with the scientific definition, whereas the sentences made about the principle of Secularism mostly contained misconceptions. In addition, it is observed that students mostly cannot make sentences about the principles of Nationalism, Statism and Revolution.

\section{Discussion and Conclusion}

Considering the complementary and interrelated characteristics of Atatürk's principles, the fact that the principles are included in the cognitive structure of the students as various parts of an organized whole and totality may indicate that Atatürk's principles were perceived to a large extent in a correct and proper manner. Other studies have also obtained findings that support this outcome (Er Tuna, 2018; Iş1klı et al., 2011). However, it can be said that the principles of Statism and Revolution are less associated with other principles. This situation can be interpreted as that the principles of Statism and Revolution are perceived in students' cognitive structures in a way that is disconnected from Atatürk's other principles.

As a conclusion of the analysis of the data, it was determined that the students most frequently associated Atatürk's principles with the concept of equality. In addition, it was seen that the students stated the concept of equality as a word in reply to all principles except Statism. In addition, the concepts of ballot paper, Turkish flag and state have been common words used for all of Atatürk's principles.

Based on the findings, it is suggestions to use the WAT method in an experimental design, to examine the conceptual changes of students in the context of Atatürk's principles and to organize teaching activities in order to prevent secondary school students' misconceptions especially about the principles of Secularism and Revolutionism at an early age.

\section{Etik Kurul İzin:}

Yapılan bu araştırmanın verileri 2019 yılında toplandığı için Etik Kurul izni alınmamıştır. Öğrenciler araştırmaya gönüllü olarak katılmışlardır. Çalışma grubundaki öğrencilere kod isim verilerek gizlilik sağlanmıştır. 